Romance Languages and Modern Linguistic Theory. Papers from the 20th Linguistic Symposium on Romance Languages, Ottawa, 10 - 14 April, 1990, ed. by Paul Hirschbühler \& Konrad Koerner, 225-250 (1992), Amsterdam: John Benjamins.

\title{
ON THE DISTINCTION BETWEEN RAISING AND CONTROL
}

\author{
Johan Rooryck \\ The Pennsylvania State University/ Indiana University
}

\section{INTRODUCTION*}

The distinction between Raising and Control verbs was introduced in generative grammar to account for two structures of infinitival complementation with different syntactic and semantic properties. Several arguments were put forward in early generative grammar by Rosenbaum (1967), Perlmutter (1970), Ruwet (1972) and Postal (1974) to justify this distinction. One of the most striking properties of Raising verbs is of course their absence of thematic and selectional restrictions on the surface subject (1), as opposed to control verbs (2). ${ }^{1}$

(1) a. Oscar semble / risque de / commence à s'évanouir/ écrire

'Oscar seems /is likely / begins to faint / to write'

b. La pierre semble / risque de / commence à tomber

'The stone seems /is likely / begins to fall'

c. Il semble / risque de / commence à neiger

'It seems /is likely / begins to snow

(2) a. Je prétends/ veux PRO être nommé directeur/ PRO partir à l'étranger

'I claim/ want to be nominated director/ to go abroad'

b. Cela/ Louis mérite de PRO être mieux connu

'This/ Louis deserves to be known better'

c. J'ai forcé Arnaud (Pat) à PRO partir

'I forced Arnaud to leave'

Hence, we will assume the rather uncontroversial structures in (3) and (4) for respectively Raising and Control verbs. For control verbs, we will simply disregard the possibility of VP and IP complementation which has been argued for by Rochette (1988).

$$
\begin{aligned}
& {[\mathrm{NP} \text { e }] \mathrm{V} \text { [IP NP - INFL - VP] }} \\
& {[\mathrm{NP} \text { NP ] V [CP [IP PRO - INFL - VP]] }}
\end{aligned}
$$

Ruwet (1983) has offered interesting arguments to show that the distinction between Raising and Control verbs is not as clear-cut, and that several syntactic and semantic factors play a role in a number of cases of infinitival complementation which he considers intermediate between Raising and Control. Ruwet (1983) claims that certain control verbs display syntactic and semantic properties that are typical of Raising verbs. I will try to show that Ruwet's arguments do not show that the Raising - Control distinction is blurred, but that quite the contrary is the case. The so-called 'Raising' properties of Control verbs can be explained by independent syntactic and semantic phenomena. In this paper, I would like to focus on the two main arguments put forward by Ruwet (1983), one argument is syntactic, the other is a semantic argument. The syntactic argument is based on the syntax of en, the semantic argument is based on the observation that the agentive properties and the aspectual properties of certain control verbs seem to disappear in certain 'figurative' uses. In both cases, I will show that the arguments invoked by Ruwet (1983) are largely independent of infinitival 
complementation. I have discussed elsewhere the other problems invoked by Ruwet (1983) to argue for a 'blurred' distinction between Raising and Control: the homonymy of certain control verbs, modals and promettre 'promise'and menacer 'threaten' is a largely descriptive problem discussed in Rooryck (1989) and certain 'metaphorical' uses of permettre 'allow', empêcher 'prevent', and soupçonner 'suspect' are dealt with in Rooryck (1988a).

\section{THE SYNTAX OF EN}

In Ruwet (1972), the distinction between Raising and Control verbs was established on purely syntactic grounds referring to the distribution of $e n$.

(5) a. L'auteur de ce livre semble être génial. (=Ruwet 1983:(2a))

'The author of this book seems to be a genius'

b. L'auteur de ce livre prétend être génial. (=Ruwet 1983:(2b))

'The author of this book claims to be a genius'

(6) a. L'auteur semble en être génial. (=Ruwet 1983:(3a))

'The author seems of-it to be a genius'

b. L'auteur prétend (* en) être génial. (=Ruwet 1983:(3b))

'The author claims of-it to be a genius'

In (6a), the clitic on the infinitive was explained as a 'testimony' of Raising to the subject position of the matrix verb. In (6b), no Raising has taken place, hence the clitic en cannot be attached to the infinitive. Ruwet (1983) tries to show that this defining property of Raising verbs indicates that certain uses of control verbs should be viewed as cases of Raising.

(7) a. Le mécanisme d'ensemble (de l'anaphore pronominale) en est connu, mais le détail mérite d'en être exposé plus soigneusement. (J.-Cl. Milner, Ordres et raisons de langue, Seuil, 1982 p. 18, cité par Ruwet 1983:(17a))

The overall mechanism (of the pronominal anaphor) of-it is known, but the details deserve of-it to be explained with more care

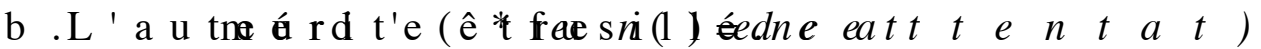
(=Ruwet 1983:(17b))

'The author deserves of-it to be executed (of-it = of this attack)'

(8) a. Le fondateur ne prétend pas (*en) être omniscient. (en= de l'empire)

(= Ruwet 1983:(24a))

'The founder does not claim of-it to be omniscient (of-it = of the empire)'

b. L a i s neep r ét epal 8 ê trreex ha u s t i ₹ed. (ceenıerbes)

(= Ruwet 1983:(24b))

'The list does not claim of-it to be exhaustive (of-it = of these verbs)'

In Ruwet's (1983) view, the (b) sentences behave as Raising structures, and he sustains his analysis by pointing to the fact that Control verbs always involve animate controllers. This last claim can easily be falsified, since a close examination of Control verbs using the lists of Gross (1975) and Busse-Dubost (1977) show that there are two control verbs with exclusively inanimate subject controllers: conspirer 'conspire' and concourir 'converge'. ${ }^{2}$

(9) (...)"tout conspire, tout concourt à faire de moi un paysan (...) Ch. Peguy, in Maurois, Etudes littéraires, tome 1 p. 24, cited Grand Robert, tome 2, p. 850, 
sub conspirer .

'Everything conspires, everything converges to turn me into a peasant'

But even independently of this issue, the claim that the (7b-8b) sentences are Raising structures is not entirely justified, since it exclusively depends on the supposed criterial value of the syntax of $e n$ as a litmus test for Raising. If it can be shown that the constraints noted in these sentences are not restricted to infinitival complementation, Ruwet's (1983) conclusion is voided.

The independent character of the syntax of $e n$ with respect to infinitival complementation can be illustrated in tensed sentences. In relative clauses, the contrast noted in (7b-8b) also shows up. Please note that the brackets indicate that en can only surface in one place at a time, either in the matrix clause or in the embedded clause.

(10) a. J'(en) ai rencontré l'inventeur, qui (*en) a été critiqué (en = du dé à coudre)

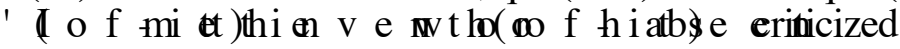
(of-it $=$ of the thimble)'

b. Il (en) a vu le chef qui (*en) est si célèbre. (en = de ce groupuscule anarchiste)

'He (of-it) saw the chief who (of-it) is very famous (of-it = of that small anarchist group)'

c. Lefondateuqui( * e rét)aiomniscien(te na)pourtané téassassiné (en = de l'empire $)$

'The founder who (of-it) was omniscient nevertheless (of-it) was assassinated (of-it $=$ the empire)'

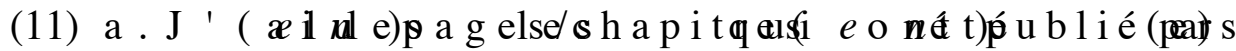
cet éminent philologue. $(e n=$ de Mensagem $)$

I (of-it) read the pages/ the chapters which (of-it) have been published by that outstanding philologist (of-it = of Mensagem)

b. Il( $e$ na)reconnuleg oût 1 acouleurl/e débuqui( $e$ ne\$ ts i frappant(e) (en = du poulet à l'estragon/de sa jupe/ de Casablanca)

'He of-it recognized the taste/ the color/ the beginning which of-it is very characteristic (of-it = of tarragon chicken/ of her skirt/ of Casablanca)'

c. Stanley n'(en) a vu que la partie qui (en) avait déjà été explorée avant lui. (en = du fleuve Congo).

'Stanley only (of-it) saw the part which (of-it) had already been explored before him (of-it = of the Congo stream)'

(12) a. J'(en) ai immédiatement édité les chapitres que j'(en) avais lus deux semaines auparavant. (en $=$ de ce livre)

'I (of-it) have immediately edited the chapters that I (of-it) read two weeks before (of-it $=$ of that book)'

b. $\mathrm{J}^{\prime}(e n)$ ai rencontré le dessinateur que j'(*en) avais aperçu à la télévision (en = de cette bande dessinée $)$

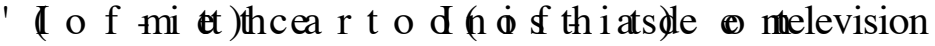
(of-it $=$ of that comic strip)'

Note that the cliticization of en which is unacceptable in the relative clauses of (10) is perfectly acceptable in simple sentences, as pointed out by Ruwet (1983):

(13) a. L'inventeur en a été critiqué

'The inventor of-it was criticized' 

b. Le chef en est célèbre
'The chief of-it is famous'
c. Le fondateur en est omniscient
'The founder of-it is omniscient'

Descriptively speaking, the contrasts noted in (7-8) and (10-11) show that a certain type of inanimate nouns can 'maintain' a syntactic relation with en over a CP boundary, whether CP is tensed or not. Note moreover that there is a minimal difference between relativized and interrogative sentences in this respect:

(14) a. Voilà les membres que vous n'(* en) avez jamais rencontrés

$($ en $=$ de ce club)

'These are the members which you (of-it) have never met

(of-it $=$ of this club)'

b. Quels membres n'en avez-vous jamais rencontrés?

'Which members of-it did-you never meet?'

The observation is confirmed by the fact that in the case of Raising structures, where there is an IP boundary, this restriction does not apply if we disregard the relative difference in acceptability between animate and inanimate nouns (15-18):

(15) a. L'auteur semble/ va/ peut/ doit en être génial (cf. Ruwet 1983:(3a))

'The author seems/ will/ can/ must of-it be a genius'

(16) a. L'auteur menace de ne jamais (??en) devenir célèbre (=Ruwet 1983:(14b))

'The author threatens never of-it to become famous'

b. La préface menace de ne jamais en être publiée (=Ruwet (1983a:(14b))

'The preface threatens never of-it to be published'

(17) a. L'auteur commence à (?en) être connu.(en $=d u$ projet $)$

(=Ruwet 1983:16b))

'The author begins of-it to become famous (of-it = of the project)'

b. La solution commence à en être connue. $(e n=d u$ problème $)$

(=Ruwet 1983:(16a))

'The solution begins of-it to become known (of-it = of the problem)'

(18) a. Le début promet d'en être imprévisible (en = de ce film)

'The beginning promises of-it to be unpredictable (of-it = of that movie)'

b. Le chef promet d'en devenir important dans la région (en $=$ de ce

mouvement révolutionnaire)

'The chief promises of-it to become important in the region

(of-it $=$ of that revolutionary movement)'

We can conclude that the phenomena noted by Ruwet (1983) do not blur the Raising Control distinction, but they actually confirm it: Raising verbs allow any type of NP to entertain a relation with en over a sentential boundary, whereas Control verbs impose a restriction on this relation with respect to the type of NP heading en. Obviously, this is not the correct way of expressing the generalization: we still have to explain why this is so.

A closer look at the type of inanimate nouns that allow en to cliticize in a sentential complement can help us explain the restriction observed more adequately. Essentially three types of nouns seem to be involved: relational nouns in the sense of Tellier (1989) and Pica (to appear) (cfr 11, 12a), 'representational' nouns in the sense of Milner (1982) and Godard (1986) (cfr 19), and Event nominalizations ${ }^{3}$ (cfr 20). Among the relational nouns, only partitive (inanimate) relational nouns allow for en to 
be cliticized in the sentential complement as shown in the contrast between (10b) and (11) or (21) and (22).

(19) a. La caricature mérite d'en être exposé (en = de Chitterrac) 'The cartoon deserves of-it to be on display (of-it = of Chitterrac)'

b. J'ai vu la caricature qui en a été faite 'I saw the cartoon that of-it was made'

(20) a. La vérification ne prétend pas en être exhaustive (en = des données) 'The verification does not claim of-it to be exhaustive (of-it = the data)'

b. J'ai assisté à la vérification qui en a finalement été entreprise 'I was present at the verification which of-it was finally undertaken'

(21) a. La sœur ne prétend pas (*en ) être omnisciente (en $=d u$ clairvoyant) 'The sister does not claim (of-it) to be omniscient (of-it $=$ of the clear sighted person)'

b. La sœur, qui n'(*en) est pas omnisciente, travaille dans une usine 'The sister, who of-it is not omniscient, works in a factory'

(22) a. Des quantités attendent d'en être distribuées gratuitement (en=de farine) 'Quantities await of-it to be distributed for free (of-it = of flower)'

b. Nous avons évalué les quantités qui en ont été distribuées gratuitement 'We evaluated the quantities that of-it have been distributed for free'

Nonrelational nouns (23-26), Agent nominalizations (10ac, 12b) and nouns expressing quality (27) (Milner 1982, Godard 1986) seem to be excluded

(23) a. Il faut essayer d'évaluer les conséquences qui (*en) sont imprévisibles. $($ en $=$ de cette décision $)$

'One must try to evaluate the consequences which (of-it) are unpredictable (of-it $=$ of that decision)'

b. Les conséquences exigent d'(*en) être évaluées

'The consequences demand (of-it) to be evaluated'

(24) a. Nous avons négocié ces conditions qui (*en )sont avantageuses

$($ en $=$ de ce contrat $)$

'We negotiated these conditions which (of-it) are interesting (of-it $=$ of this contract)

b. Les conditions méritent $\mathrm{d}^{\prime}(* e n)$ être étudiées

'The conditions deserve (of-it) to be investigated'

(25) a. La porte prétend (??en) rester fermée tout l'après-midi (en = de la cathédrale) (=Ruwet 1983:(54))

'The door claims (of-it) to remain closed all afternoon'

b. J'ai vu la porte qui (?*en) a été construite avant 1666 'I saw the door which of-it was build before 1666'

(26) a. Les semelles exigent/ attendent $\mathrm{d}^{\prime}\left(?^{*}\right.$ en $)$ être réparées. (cfr Ruwet (1983a:(56))

'The soles demand / wait (of-it) to be repaired'

b. Ce sont les semelles qui n'(?*en) ont pas été réparées

'It is the soles which (of-it) were not repaired' 
(27) a. La gentillesse mérite $\mathrm{d}^{\prime}(* e n)$ être soulignée (en = des indigènes) 'The kindness deserves (of-it) to be underscored (of-it $=$ of the natives)

b. Ils (en)ont souvent regretté la gentillesse qui (*en) est exceptionnelle 'They (of-it) often regretted the kindness which (of-it) is exceptional'

These additional data give us an idea of where to look for an explanation of the restrictions noted. Chomsky (1986) establishes a difference between 'inherent' case and 'structural' case, where 'structural' case is assigned in S-structure and is relatively independent of $\square$-marking, whereas inherent' case is assigned in D-structure and is closely linked to $\square$-marking. For our purposes, we will make abstraction of this link with $\square$-marking. For Chomsky (1986), inherent case is a case of DS affixation of an affix POSS to the subject of NP, and realized on NP in that position (Chomsky 1986:188). The context in which POSS is inserted is the following:

$$
\text { [NP NP__] }
$$

Notice that the nouns allowing cliticization of $e n$ in the embedded clause subcategorize for the en complement which represents the complement 'produced' by the Event nominalization (20), 'represented' by the representational noun (18), or 'partitioned' by the relational partitive nouns $(7 \mathrm{a}, 11,12 \mathrm{a}, 22)$. When cliticization of $e n$ in the sentential complement is excluded, en corresponds to the Theme of 'quality' nouns (27), to a part -whole relation that cannot be termed both relational and partitive $(23-26,10 \mathrm{~b})$, or to a purely 'relational' quality (21). Agent nouns (6b) and Agent nominalizations (10ac) also exclude the cliticization of en in the sentential complement, minimally contrasting in this respect with Event nominalizations (20).

For the cases in which the en complement can be termed the 'object' of the head noun (Event nominalizations, representational nouns and partitive nouns), it seems reasonable to assume that this en complement receives structural (objective or partitive) case from the head noun before cliticization. This is what explains the simple cases where no CP boundary intervenes between the noun and en. ${ }^{4}$
(29) a. La production en a été améliorée
'The production of-it was ameliorated'
b. La caricature en est excellente
'The cartoon of-it is excellent'
c. Des quantités en ont été vendues
'Quantities of-it were sold'

In case a CP boundary intervenes between en and the head noun, structural case can be transmitted from the head noun to the Wh- operator in the Spec of CP or to PRO in the Spec of IP as part of the $\square$-features \{person, number, gender, Case which the antecedent shares with the operator or PRO by, respectively, government and control. Consequently, all of the cases where $e n$ has an 'object' relation to the head noun are acceptable.

The en complements that do not have this 'object' relation can only receive inherent case from their head noun before cliticization in the simple cases:

(30) a. Les semelles en sont usées

'The soles of-it are worn out'

b. Les conditions en sont avantageuses

'The conditions of-it are interesting'

c. La gentillesse en a été soulignée

'The kindness of-it has been underscored' 
For Agent nouns and Agent nominalizations, we have to accept that structural objective case cannot be assigned. It is not unreasonable to formulate the hypothesis that the agentive morpheme of Agent nominalizations blocks the case assignment properties of the verb it is derived from. The idea behind this is that only Events (or eventualities), nominal or verbal, can assign objective case. Consequently we will assume inherent case for these en complements as well.

\section{(31)}

\section{L'auteur/ le fondateur en est célèbre 'The author/ founder of-it is famous'}

In case a $\mathrm{CP}$ boundary intervenes between en and the antecedent of the Wh- operator or PRO in these cases, en is excluded because of the fact that inherent case cannot be assigned. The main reason for this is that the context (28) which is necessary for the assignment of inherent case is not met: in D-structure, no lexical NP is present to assign inherent case: PRO or a Wh- operator clearly cannot be assumed to assign inherent case. In this case, it cannot be argued that inherent case is inherited from the antecedent via $\square$-features. First of all, it does not seem likely that morphological (inflectional) features are checked at D-structure. Even if this was the case, however, the Wh- operator or PRO are too far away to inherit inherent case by government or by control, since it is generally accepted that the NP heading $e n$ originates in a complement position. The relative clauses and the control structures which involve inherently case- marked en are thus correctly ruled out by general principles of Case theory. Note that in Raising structures (14-17) and in interrogative sentences (14b), assignment of inherent case in D-structure is possible since the context (28) is met. Contrary to Ruwet's (1983) claims, the interaction of the syntax of en and infinitival complementation actually underscores the difference between Raising and Control structures.

One last question concerns the scope of the restriction noted: why is structural case only assigned by Event nouns (see fn. 3) and nominalizations, partitive relational nouns and representational nouns? What is the generalization unifying these types of nouns? It is a little strange to say that partitive nouns or a fortiori representational nouns subcategorize in some way their complement, even if only case is involved. A possible solution can be found if one is willing to accept a relationship between quantification and the structure of Events. ter Meulen (1989, forthcoming) shows that aspectual classes can be represented in a Generalized Quantifier framework as types of quantification. If one is allowed to view an Event as a quantification 'measured out' (Tenny 1988) over the complement, the relevant generalization with respect to structural case in NPs headed by Event nominalizations could be stated in terms of quantification over the complement. Likewise, for representational nouns one might say that that they conceptually 'freeze a moment in time', that they represent a subset of a larger entity. Note that this kind of relation is completely absent in the nouns assigning inherent case: either there is no subset relation (30ab), or there is a relation of predication (30c). If this hypothesis is correct, structural 'objective' and 'partitive' case in French NPs would be essentially identical at the appropriate level of abstraction: structural 'partitive' case in French would express both an aspectual property and a purely partitioning property. This situation is reminiscent of Finnish, where the progressive aspect and the partitive quantifier are expressed by the same morpheme (Carlson 1981, Tenny 1987). Note that Event nominalizations have to be interpreted aspectually not as Events but as Eventualities (Carlson 1984), an epistemic nonpunctual notion. Of course this can hardly be a coincidence: it suggests that a comprehensive theory of Event and Noun quantification in a UG framework may elucidate several problems presently stated in terms of Case or thematic roles. A very preliminary answer to part of this problem 
involving the relation between aspect and thematic roles will be addressed in the following paragraph.

\section{3. 'FIGURATIVE' USES, ASPECT, AND THEMATIC STRUCTURE}

A second test used by Ruwet (1983) to distinguish Raising and Control verbs following Burzio (1981) - is the possibility to insert these verbs in a causative construction. The causative verbs faire 'make' and laisser 'let' and the perception verbs cannot select Raising verbs.

(32) a. * Cette mauvaise nouvelle le fait sembler être malade

'This bad news makes him seem to be sick'

b. * Nous avons entendu/ vu Jean-Louis s'avérer ne rien avoir compris

'We heard/ saw Jean-Louis appear to have understood nothing at all'

In Rooryck (1990), I have shown that this restriction on the selection of Raising verbs is not a syntactic one as claimed by Burzio (1981), but rather results from a semantic contradiction between causation or perception and a probable event. ${ }^{5}$ The exclusion of Raising verbs does not seem to be complete: the class of aspectual verbs studied by Lamiroy (1987), which we would like to view as Raising verbs (cfr Rooryck 1989), can combine with causative and perception verbs.

(33) a. Je leur ai fait commencer à manger la tarte

'I to-them made begin to eat the pie'

b. J'ai vu l'eau commencer à inonder les prés

'I saw the water begin to inundate the meadows'

However, Ruwet (1983) considers these verbs as ambiguous between Raising and Control. Recall Ruwet (1983) defends the hypothesis that certain uses of Control verbs behave as Raising verbs. He observes that certain verbs can be inserted in a causative contruction if they have an animate subject, but not if they have an inanimate subject:

(34) a. Le salaire intéressant a fait accepter à Fernand de devenir général 'The nice salary made Fernand accept to become a general'

b * L'évolution de la science a fait accepter à cette théorie d'être modifiée 'The evolution of science made that theory accept to be modified'

(35) a. Sa bonne volonté/ Le roi fait admettre au général d'être relevé de ses fonctions. (=Ruwet 1983:40a))

'His good nature/ The king makes the general admit to resign'

b. * Le critique/ Son inélégance fait admettre à la solution d'être révisée (=Ruwet 1983):40b))

'The critic/ Its lack of elegance makes the solution admit to be revised'

In Ruwet's (1983) view, Raising verbs stricto sensu (the ones modifying the relation between appearance and reality: sembler 'seem', s'avérer'appear'), cannot be combined with causative and perception verbs. Ruwet (1983) then explains specific uses of Control verbs which exhibit the same property by equating these uses with Raising structures.

This solution is not completely satisfactory for a number of reasons. A first problem for Ruwet's (1983) analysis is an empirical one: Raising verbs are not the only verbs 
that cannot combine with causatives. Stative control verbs are always excluded from causative or perception verbs whether their subject is animate or inanimate.

(36) a. * Ces circonstances lui ont fait mériter/ avoir des chances d'être prise au sérieux. (lui = Bérangère/ cette théorie)

'These circumstances made him/her deserve / have a chance to be taken seriously (him/her = Bérangère/ this theory)'

b. ? Sa bravoure lui a fait mériter d'être décoré

'His recklessness made him/her deserve to be decorated'

This aspectual restriction on Stative verbs is a general one which is not limited to Control verbs:

(37) a.*? Les vicissitudes du marché ont fait équivaloir les pertes de cette société aux gains de l'année passée.

'The unpredictable character of the market made the losses of that company be equivalent to the gains of last year'

b.* Je fais/ vois/ entends convenir cette situation à Marc/ consister ce livre en trois parties.

'I make/ see/ hear that situation be convenient to Marc/ that book consist of three parts'

Causative faire 'make' and laisser 'let' allow for exceptions in this respect if the subject of the Stative infinitive inherently (38) or contextually (36b) possesses the ProtoAgent feature (Dowty 1988) Sentience or Volition. If Statives combine with causatives, they receive an inchoative interpretation, ${ }^{6}$ but it must be noted that statives can only occur in causative constructions if they have the Proto- Agent feature Volition or Sentience: compare (37) and (38):

(38) a. Je lui ai fait aimer/ vouloir cela

'I made him/her love/ want it'

b. Je lui ai fait/*vu/* laissé connaître cette ville/ savoir que tout était fini

'I made/ saw/ had him/her get acquainted that city/ know that everything was finished'

To come back to Ruwet's (1983) hypothesis, the contrast noted in (34-35) seems only to be valid for what Melis (1983a) has called 'transparent' verbs. Ruwet (1983) notes that the inanimate character of the subject of these verbs corresponds to a 'figurative' interpretation where the agent is absent: (8b, 21a, 23b). I quote Ruwet: '(...) Tout se passe comme si l'auteur, modestement, s'effaçait derrière ses propres productions; il reste à l'arrière-plan, tout en étant impliqué dans le contenu de la phrase.' (Ruwet 1983a:30). He adds that the interpretation of (39a) can be paraphrased as (39b):

(39) a. La liste ne prétend pas en être exhaustive. (=Ruwet 1983:57))

'The list does not claim of-it to be exhaustive'

b. Je ne prétends pas que la liste en est/ soit exhaustive. (=Ruwet 1983:58))

'I do not claim that the list of-it is exhaustive'

This 'figurative' interpretation is always absent in Stative Control verbs of the mériter 'deserve' type: (7b, 18a, 27a).

The parallelism Ruwet (1983) tries to establish between the inacceptability of Raising verbs and 'figurative' uses of Control verbs would be justified if these figurative uses of Control verbs were limited to infinitival constructions. Even if its status in a generative 
grammar remains unclear, the phenomenon causing one verb class to exert an 'iconic' influence on another semantically related verbs class is a well known one. The argument structure of the 'iconically influencing' verb is adopted by the related verb. This phenomenon has been studied for the class of French intransitive verbs such as aboyer 'bark', scintiller 'sparkle', grésiller 'crackle' (Gross 1975), which may enter the transitive scheme of dire 'say' type verbs with an infinitival complement, and for intransitive movement verbs, which may enter the scheme NP Vmvt Vinf (Lamiroy 1983).

(40) a. Le colonel lui a aboyé de se taire. 'The colonel barked to him to shut up'

b. Il nage prendre la balle. 'He swam (to) take the ball'

However, a similar 'iconic' explanation where one verb class with infinitival complementation, in casu Raising verbs, would influence the class of Control verbs is excluded here for two reasons.

A first theoretical reason has to do with the classical definition of Raising verbs formulated in the introduction. If this definition is accepted, Raising verbs constitute semantically well defined classes: verbs modalizing our perception of reality (epistemic pouvoir 'may' and devoir 'must', sembler 'seem', s'avérer 'appear', faillir, manquer 'to very nearly get $x$-ed'), aspectual verbs concerning the modality of realization of the event (commencer 'begin', être en train 'be x-ing', finir 'finish'), and temporal verbs expressing short term future (aller 'go') and past (venir de 'just have'), or imminence (promettre 'promise', menacer 'threaten', risquer 'risk'). An explanation of the 'figurative' uses mentioned should at least give an indication of the semantic class that 'iconically' influences the figurative use of the verbs mentioned. Under the 'iconic' analysis, it would be strange to observe that the syntactic structure of the Raising verbs is superimposed on the figurative control verbs, but that their semantic properties are not.

A second reason is that the 'figurative' use can also occur independently of infinitival complementation:

(41) a. Ce chercheur prétend l'inverse. 'This researcher claims the contrary'

b. Ces résultats prétendent l'inverse. 'These results claim the contrary'

(42) a. Fernand accepte le poste de général

'Fernand accepts the job of a general'

b. Cette théorie n'accepte pas de modifications

'That theory does not accept changes'

(43) a. Le général admet son erreur

'The general admits his error'

b. Cette solution admet une certaine variation

'This solution admits a certain variation'

As can be expected, the (b) sentences do not combine with causative or perception verbs

(44) a. Tout le monde a vu/ laissé ce chercheur prétendre l'inverse 'Everybody saw/ let that researcher claim the contrary'

b. * Tout le monde a vu/ laissé ces résultats prétendre l'inverse Everybody saw/ let these results claim the contrary' 
(45) a. Le public a vu/ laissé le général admettre son erreur 'The public saw/ let the general admit his error'

b. * Le public a vu/ laissé cette solution admettre une certaine variation 'The public saw/ let that solution admit a certain variation'

This impossibility suggests that (41-43) should rather be explained on a par with the exclusion of Stative verbs illustrated in (37). This means that the 'figurative' uses of the verbs mentioned have to be analyzed as Stative verbs, as opposed to their nonfigurative aspectual status as 'accomplishment' or 'achievement' verbs, in Dowty's (1979) terminology, or as 'Transitions' to use Pustejovsky's (1988) terms. This conclusion is corroborated by Ruwet's observation that 'figurative' uses loose the possibility of a punctual interpretation.

(46) a. Le délégué du parti a immédiatement/ brusquement accepté/ admis

d'être remplacé. (= Ruwet 1983:(50a))

'The party delegate immediately/ suddenly accepted/ admitted to be replaced'

b. * La solution du problème a immédiatement admis/ accepté d'être révisée (=Ruwet 1983:(50b))

'The solution of the problem immediately/ suddenly admitted/ accepted to be revised'

(47) a. L'inculpé a aussitôt prétendu être innocent de tout reproche.

(= Ruwet (1983a:(53a))

'The accused immediately claimed to be blameless'

b. * La liste des verbes a aussitôt prétendu être exhaustive.

(= Ruwet 1983:(53b))

'The list of verbs immediately claimed to be exhaustive'

Ruwet (1983) tries to link the nonpunctual interpretation of the 'figurative' uses to the nonpunctual character of Raising verbs stricto sensu, but he admits that these verbs only exhibit a preference for punctual interpretations: they do not exclude this interpretation altogether as the 'figurative' uses do.

(48) a ? Au moment d'envoyer cet article à l'impression, les conclusions m'ont brusquement paru en être incorrectes. (= Ruwet 1983:46b))

'When I was just about to send this article to the editor, the conclusion suddenly appeared to me of-it to be incorrect'

b. $\quad$ La solution vient juste de s'avérer en être correcte. (= Ruwet 1983:48)) 'The solution just appeared of-it to be correct'

Stative verbs and 'figurative' uses however pattern together in their (relative) exclusion of punctual interpretations:

(49) a. * Louis vient de mériter d'être décoré

'Louis just deserved to be decorated'

b. *? Cette solution a brusquement mérité d'être adoptée

'This solution suddenly deserved to be adopted'

This change in aspectual characteristics of course recalls other well known phenomena of aspectual change where, to use Tenny's $(1987,1988)$ terminology, nondelimited verbs can become delimited. These phenomena have been extensively studied by 
Vendler (1967), Verkuyl (1972), Dowty (1979), Dahl (1981), Tenny (1987, 1988), van Voorst (1988), and Pustejovsky (1988), among others.

(50) a. Alan walks

b. Alan walks to the park

(51) a. Catherine eats

b. Catherine eats an apple (nondelimited, Process)

(delimited, Transition)

(nondelimited, Process)

(delimited, Transition)

In these cases, the presence or absence of the complements of the verb affects the aspectual structure but not thematic structure. In the case of the 'figurative' uses, we are in the presence of a slightly different phenomenon, since the aspectual structure is changed through a change of the properties of the subject which does affect thematic structure. When a Transition verb becomes a Stative verb through 'figurative' use, the Agent properties of the subject disappear altogether. To be more precise, none of the Proto- Agent features Causation, Sentience, Volition or Movement seem to be present on the subject of the 'figurative' sentences. In thematic terms, the Agent disappears to become a Theme.

How can this state of affairs be reconciled with the $\square$-criterion (Chomsky 1981, 1986)? The $\square$-criterion states that every argument of a verb should be visible in a chain containing a $\square$-position (Chomsky (1986:97). The only way to satisfy the $\square$-criterion for verbs whose arguments appear to have two different $\square$-roles in respectively the 'figurative' and 'nonfigurative' uses would be to postulate homonyms. In view of the productivity of these uses (cfr Ruwet 1972:V), this does not seem a viable option. In the remainder of this article, I will try to develop a tentative answer to this question. In order to do so, we obviously need a framework that addresses the question of the relation between aspect and thematic structure. Tenny's (1987, 1988) Aspectual Interface Hypothesis addresses exactly this issue. This hypothesis states that thematic roles are part of the cognitive conceptual structure and are as such not visible to the grammar: thematic roles are mapped into the grammar by the aspectual structure of the verb (Tenny 1987, 1988). I will adopt here a weaker version of the AIH, claiming that in addition to aspectual properties, Agent properties also must somehow be visible to the grammar. This weaker version simply reflects the work of Dowty (1988), who argues for a view of argument structure where no reference is made to thematic roles except for Agent properties, and the aspect calculus of Pustejovsky (1988) who explicitly integrates Agent properties into a formal representation of the aspectual structures of sentences.

In order to account for sentences like (50-51), we obviously need a mechanism in the grammar that assigns aspectual structure to a sentence interacting with lexical insertion in D-structure. This mechanism can be viewed as flexible enough to accommodate transgressions of 'normal' selectional properties in the lexical insertion, and assign the 'deviant' sentence aspectual properties. As long as the sentence is not conceptually 'too deviant' in a sense to be made more precise (cfr infra), the aspectual properties assigned do not change. This can be illustrated by 'psych'-verbs such as amuser 'amuse', ennuyer 'bother' which have both agentive and nonagentive uses, and by the 'figurative' 'psychological' use of 'physical' verbs such as écraser 'crush', frapper 'strike', abattre'knock down'. Ruwet (1972:V) and Bouchard (1990, this volume) show that this is an extremely productive grammatical process in French that cannot be simply resolved by positing two homonymous thematic structures. In its purely 'psychological' use, nonagentive Stative frapper 'strike' means 'impress'. 
(52) a. Mélanie a brusquement frappé Jules

'Mélanie suddenly struck Jules'

b. *? Cette nouvelle a brusquement frappé Jules

'This news suddenly struck Jules'

c. Le public a vu/ laissé Mélanie/ *cette nouvelle frapper Jules

'The public saw/ let Mélanie/ this news strike Jules'

Adopting Dowty's view of Proto- Agent properties, one can say that in this particular nonagentive use, none of the properties Causation, Sentience, Volition or Movement are present. Ruwet (1972) notes however that a lot of intermediate uses between the 'physical' and the 'psychological' meanings are possible. Strikingly, the properties of Causation and perhaps Movement can be attributed to the subject of these sentences, and the sentence retains its normal, nonfigurative aspectual properties displayed in (52a). Contrary to (52b), in (53) frapper means 'cause harm', still slightly differing from its nonfigurative meaning 'strike'.
a . L em a $1 \mathrm{~h}$ eauprl u s i e fi $\boldsymbol{\emptyset} \dot{\mathbf{s}} \mathbf{b}$ t u s q u e mfermatp p é $\mathrm{t}$ famille
( $\mathrm{R}$ fu 1972:236(199))
'Hardship struck that family several times/ suddenly'
b. J'ai vu le malheur frapper plusieurs fois cette famille 'I saw hardship strike that family several times'

These observations can be extended to the 'figurative"psychological' uses of transitive movement verbs in French such as conduire 'lead', amener 'bring' (Melis 1983b).

(54) a. J'ai (brusquement) conduit Hippolyte dans son bureau 'I (suddenly) lead Hippolyte to his office'

b. Cette situation a (brusquement) conduit Hippolyte au désespoir 'This situation (suddenly) lead Hippolyte to despair'

(55) a. J'ai vu mon frère conduire Hippolyte dans son bureau 'I saw my brother lead Hippolyte to his office'

b. J'ai souvent vu ce genre de situations conduire Hippolyte au désespoir 'I have often seen that kind of situations lead Hippolyte to despair'

The important point of course is that as long as certain Agent properties (Causation, Movement) are present, the aspectual structure of the sentence does not change. Or, to state it more generally, minor changes in Agent properties are not mirrored in aspectual structure. ${ }^{7}$ When Agent properties disappear altogether, aspectual structure is modified. The question is of course why this should be so. We would like to suggest that an aspectual reinterpretation of the $\square$-criterion is responsible for this state of affairs. This reinterpretation might be stated as follows:

Every argument structure must have an aspectual type (e.g. State, Process, Transition) that is compatible with the (lexically determined) aspectual (sub)event structure of the verb in the argument structure

This criterion ensures the aspectual changes noted in (51) which depend on the lexical insertion of the arguments. When lexical insertion creates an (active) sentence of a Transition verb such as accepter 'accept', prétendre 'claim' or admettre 'admit' where no Agent properties can be predicated of the subject, as is the case in 'figurative' uses of Control verbs or in the 'psychological' uses of verbs expressing 'physical' events, no Transition aspectual structure can be assigned to the sentence, since the agentive 
subevent (Pustejovsky 1988) is completely suppressed. Of course, the subject of the verb must receive a $\square$-role, or in our terms, the sentence must receive an aspectual structure, and it is the aspectual property of the second subevent of the Transition, a State, which prevails ${ }^{8}$. In traditional thematic terms, the verb receives a Theme role. Notice that the principle (56) retains the spirit, if not the goal, of the $\square$-criterion. In his insightful discussion of the $\square$-criterion, Jackendoff (1987:fn.7) observes that: 'the objective of the $\square$-criterion is to make sure that NPs do not acquire additional $\square$-roles in the course of a derivation'. The principle (56) does exactly this by ensuring an aspectual structure in D-structure which cannot be changed in the derivation.

Much the same can be said about Process verbs such as attendre 'wait'. ${ }^{9}$ In this case, however, suppression of Agent properties Volition and Sentience cannot force the verb to take the aspectual structure of Stative verbs, because no such subevent is present in the aspectual structure of this Process verb.

(57) a. Nicéphore attend la publication de ses œuvres complètes

'Nicéphore awaits the publication of his complete works'

b. La seconde partie attend encore la publication (cfr Ruwet 1983:(28))

'The second part still awaits publication'

c. Mon éditeur a laissé la seconde partie attendre la publication pendant 20 ans 'My editor let the second part await publication for 20 years'

Instead, attendre 'wait' in (57b) receives a nonagentive Process aspectual structure much resembling that of tomber 'fall'.

What this amounts to is a view of aspectual structure in which thematic Agent properties are dependent on aspectual structure, a view which we think is compatible with Tenny's $(1987,1988)$ AIH. A further possible consequence of this view is that changes in the relation between thematic agent properties and aspectual structure ultimately interfere with the mapping of arguments in D-structure. Haiik (1990) argues that the figurative use of tell, which she calls a 'psych' use of tell, displays all the characteristics of 'psych'- verbs.

(58) a. This noise tells me the children are back (=Haïk 1990:(1))

b. The noise *told/ reminded me suddenly that the children were back

Haik (1990) assumes a theory of argument structure which presupposes $\square$-role labels in the lexical entry of the verb. In view of the analysis of Belletti and Rizzi (1988), who argue for the derived nature of the surface subject of annoy -type psych verbs, she assumes a lexical process of internalization of the Actor role. If I understand her correctly, the Agent becomes an internal argument of the verb, and plays a role as Cause. Even if it is difficult to evaluate the relative implications of both analyses at this point, it seems that this case strongly resembles (52b), where we argued that the agentive properties are completely suppressed in the aspectual structure of the verb. (58b) shows that 'figurative' tell is a noncausative Stative verb, contrary to causative remind, a Transition verb. In (58), tell is equivalent to Stative indicate, show. Tenny (1987:306) has argued that mapping principles for the subject of 'psych' verbs can be reformulated in aspectual terms, but it seems that the presence or absence of certain Proto- Agent properties may affect this mapping as well. This is of course a topic for further research. ${ }^{10} \mathrm{~A}$ final consequence of this view is that we might be able to construct at the same time a much more dynamic and a much more constrained view of argument structure. More dynamic, because the subject argument of a verb can end up 
with different conceptual $\square$-roles in different sentences, but only one at a time. More constrained, because there is only reference to a limited set of aspectual classes (States, Processes, and Transitions, Pustejovsky 1988) and their combinations.

\section{CONCLUSION}

Contrary to Ruwet's (1983) claims, we can safely say that the distinction between Raising and Control verbs can be fully maintained. The arguments presented by Ruwet (1983) against a strict distinction of Raising and Control were shown to belong to independent phenomena. The syntax of en actually offered an additional argument in favor of the distinction mentioned. In addition, the syntax of en seems to require a distinction in terms of inherent and structural case that may ultimately be linked to quantification. In the case of the 'figurative' uses of control verbs, we were able to show that these uses are not limited to infinitival complementation. We argued that these uses of control verbs, and 'figurative' uses in general, should be viewed in the much larger context of the interaction of thematic agent properties and aspectual structure. In this context, it might be necessary to reinterpret the $\square$-criterion along the lines of (56) as a principle assigning aspectual properties to argument structures in D-structure.

\section{FOOTNOTES}

* I would like to thank Richard Kayne, Ludo Melis, Pierre Pica, Pierre Swiggers, Ellen Woolford and Liliane Tasmowski for comments on earlier versions of this paper. They of course do not necessarily agree with the contents of this version. Special thanks go to Nicolas Ruwet for extremely detailed and incisive comments on a preceding version of this paper which was published as Rooryck (1990).

${ }^{1}$ This does not mean that the infinitive alone determines all semantic properties of the Raising structure. As pointed out to me by Nicolas Ruwet (p.c.), Raising verbs such as sembler 'seem' can make embedded sentences that are semantically anomalous perfectly acceptable:

(i) Ce cercle semble être carré 'This circle seems to be square'

Following Chomsky (1981, 1986), we will accept that Raising structures select an IP complement rather than a CP. In the case of (1) and (15-17), this analysis raises the question of the status of the element introducing the infinitive, since it can neither be a complementizer nor a preposition. Essentially for this reason, Kayne (1980) excludes these verbs from the class of Raising verbs, but this analysis leaves unclear why the subject of these verb does not appear to have a $\square$-role. Descriptively speaking, all Raising verbs with aspectual restrictions on their infinitival complement have a preposition-like element introducing the infinitive (see Rooryck 1989). Notice the minimal difference between venir de 'just have' and aller 'go', the traditional 'auxiliaries' of the passé récent and the futur proche. The former, which has a preposition-like element, displays aspectual restrictions, the latter, without such an element does not have such a restriction:

(i) ?? Ce livre vient de convenir à Louis $\quad$ 'This book has just pleased Louis'

(ii) Ce livre va convenir à Louis. 'This book is going to please Louis'

Lamiroy (1987a) offers an insightful description of the aspectual restrictions applying to aspectual verbs of the commencer 'begin', finir 'finish' type. Bouchard (1987:fn.6) suggests that these preposition-like elements appear in the head of IP. I would like to follow up on this suggestion and claim that these elements should be considered morphemes on the head of IP which mark the aspectual restrictions imposed by the matrix Raising verb on its infinitival complement. 
${ }^{2}$ Two uses of conspirer 'conspire' should be distinguished. Robert (1985) treats the use of conspirer 'conspire' with an inanimate subject as an indirect transitive verb meaning 'contribute to the same effect' and not 'prepare a conspiracy'. The Trésor de la langue française notes that this use 'slips toward' indirect transitivity. The examples quoted leave no doubt with respect to the existence of this second figurative use of conspirer 'conspire':

(i) 'Les événements conspirent tous à ce but' (Verlaine, Souvenirs et fantaisies, 1896, quoted TLF sub conspirer)

'The events conspire all to that goal'

${ }^{3}$ Probably the correct generalization is not restricted to Event nominalizations, but simply to Event nouns. The noun solution, for instance (but not condition cfr (24)) can be viewed as an Event noun, but it is only diachronically a nominalization. Ruwet (1983) quotes an example with solution heading $e n$ in the embedded clause confirming our analysis:

(i) La solution ne supporte pas d'enêtre altérée $(e n=$ de ce problème $)(=\operatorname{Ruwet}(1983:(26 \mathrm{~b}))$ 'The solution does not bear of-it being altered (of-it $=$ of the problem)

(ii) La solution admet/ accepte/ tolère d'en être révisée $(e n=$ de ce problème) (=Ruwet (1983:(29b))

'The solution admits/ accepts/ tolerates of-it to be revised (of-it $=$ of the problem)'

Notice also that histoire 'history/ story' can function as a representational noun:

(iii) L'histoire exige d'en être réécrite (en = de la révolution) (= Ruwet 1972:(21c))

'The history requires of-it to be rewritten (of-it $=$ of the revolution)

${ }^{4}$ Godard (1986) argues that the 'object' of representational nouns is not subcategorized by these nouns. However, subcategorization is not a necessary condition for casemarking: In ECM verbs, the objective case is assigned to the subject of IP which is not subcategorized by the ECM verb. This may confirm Chomsky's (1986) view of structural case as independent of $\square \square$ marking. See $\S 2$. in fine however.

${ }^{5}$ See Rooryck (1988b) for further observations concerning Burzio's (1981) analysis of causatives. Burzio $(1981,1986)$ explains the examples (32) by Proper Binding. However, this configurational explanation does not account for the fact that tensed sentences corresponding to (32) are equally unacceptable:

(i) * Les circonstances on fait qu'il semble travailler à sa thèse jour et nuit 'Circumstances have made that he seems to work on this thesis day and night'

(ii) * J'ai entendu/ vu que Jean-Louis s'est avéré n'avoir rien compris 'I heard/ saw that Jean-Louis appeared not to have understood a thing'

Note that the explanation by contradiction does not apply to the exclusion of Stative verbs from causative constructions, which is an aspectual restriction imposed by the matrix verb on the infinitival complement. Compare (37) and (iii-iv)

(iii) Les vicissitudes du marché ont fait que les pertes de cette société équivalent aux gains de l'année passée

'The unpredictable character of the market made that the losses of that company were equivalent to the gains of last year'

(iv) Je fais/ vois/ entends que cette situation convient à Marc/ que ce livre consiste en trois parties. 'I make/ see/ hear that that situation is convenient for Marc/ that book consists of three parts'

${ }^{6}$ I owe this last observation to Teun Hoekstra. 
${ }^{7}$ This observation could be interpreted as an indication that there is no one-to-one correspondence between conceptual structure (Jackendoff 1987) and the semantic - aspectual structure relevant to the syntax. For interesting consequences of this view with respect to the explanation of control phenomena, see Rooryck (forthcoming).

${ }^{8}$ This explanation can also be applied to cases where no figurative use is implied in the change of a Transition to a State aspectual structure. van Voorst (1988) discusses examples from Dutch such as the following which are Stative constructions derived from Transition (accomplishment) verbs:

(i) Deze bal gooit niet lekker (*naar Marie)

'This is not a good ball to throw (to Marie)'

(ii) Piet gooit de bal naar Marie

'Piet throws the ball to Marie'

(iii) Dit papier schrijft (*de boodschap) niet lekker

'This paper is not easy to write (the message) on'

(iv) $\quad \mathrm{P} \quad \dot{\mathrm{s}}$ ce bt be io njo fol tdsppipieht a p

'Piet writes a message on this paper'

As observed by van Voorst (1988), in these sentences a property is being predicated of the subject. In our terms, the agentive subevent is suppressed, and the Stative subevent delimiting the verbal action prevails. We cannot possibly do justice to these very interesting cases in a footnote. Some of the examples van Voorst (1988) quotes involve structures where an adjunct Instrument can become the subject of the sentence.

(v) Dit mes snijdt (*het vlees) beter 'This knife cuts (the meat) better'

(vi) Deze pen schrijft (*de brief) lekker 'This pen writes (the message) well'

(vii) Deze schoenen lopen lekker (*over de weg)

'These shoes are convenient to walk in (on the road)

However, the impossibility of the direct object in (v-vi) cannot be analyzed on a par with examples (i, iii and vii). In the dialect I am familiar with, these sentences can be inserted in a causative construction, unlike the examples in (i, iii and vii). This suggests that the subject of these sentences still has an agentive property. Moreover, these sentences express a generic value, which is not the same as a State. With generic direct objects, the sentences (v-vi) are fine. Notice that in these cases the complement delimiting the Transition (accomplishment) cannot appear, suggesting that these sentences have a generic Process event structure. A deontic interpretation of capacity is possible:

(viii) Deze pen schrijft duidelijkere brieven $(*$ op papier)

'This pen (can) write(s) easy-to-read letters (on paper)'

(ix) Dit mes snijdt etenswaren beter (*in stukken)

'This knife (can) cut(s) food better (in pieces)'

Again, this shows the relation between nonpunctual aspect and quantification. It might be the case that in structures where an adjunct ends up in subject position like (vii), the aspectual structure of State is assigned as a default value. This might explain the idiomatic character of these examples where the adjunct beter/ lekker 'better/ well' is obligatory and ranges over a very restricted set of adverbs.

${ }^{9}$ van Voorst (1988:23) treats wait as a Stative verb. However, the French counterpart attendre can be an infinitival complement to aspectual verbs such as commencer 'begin' and être en train de 'be x-ing' which do not normally take Stative verbs as observed by Lamiroy (1987a).

(i) Comme il venait de le rater, Louis a commencé à attendre le tram suivant 'Since he just missed it, Louis started waiting for the next trolley' 
(ii) La seconde partie est en train d'attendre la publication 'The second part is awaiting publication'

Lamiroy (1987a) observed that Stative verbs can be selected by aspectual verbs if the Stative verb is serialized. Notice that no such serialization effect is present in (i-ii), contrary to (iii):

(iii) Après ??une seule/ plusieurs visite(s), Louis a commencé à aimer la glace/ savoir l'anglais/ connaître la ville/ voir ces défauts.

After a single/ several visit(s), Louis began to like icecream/ know English/ the city/ see those defects'

This shows that precise tests can be used to tell Stative and nonstative verbs apart.

${ }^{10}$ Another interesting problem is the relationship between aspectual changes and idiomatic structures. Lamiroy (1987b) shows that the 'physical/ psychological' metaphor is also very productive for movement verbs, and notes that this metaphor restricts the syntactic properties of these verbs.

(i) Luc a mis les clés sous le tapis. (=Lamiroy (1987b:(39a))

Luc y a mis les clés. (=Lamiroy (1987b:(39b))

(ii) L u lcua a i s o ul se ss e uqxu let a r li e $\mathrm{r}$ o $\mathrm{m}$ pe $\mathrm{L}$ a m i(rlogy8 $7 \mathrm{~b}:$ ( 40 a ) )

* Luc y a mis que Marie le trompe.(=Lamiroy (1987b:(40b))

This is also true of several examples of 'psych' verbs quoted by Bouchard (1990) (see also fn. 9, and Rooryck (1988a)).

(iii) Paul a donné un livre à Sophie Paul le lui a donné

(iv) Paul a donné libre cours à son colère

* Paul lui/y a donné libre cours
'Paul gave a book to Sophie'

'Paul it to-her gave'

'Paul gave free expression to his wrath' 'Paul to-it gave free expression'

The exact nature of these syntactic restrictions is not entirely clear, but it seems that a framework assigning aspectual structure in D-structure along the lines of (56) may allow for these structures to be investigated in a manner that is less stipulative. 


\section{REFERENCES}

Belletti, Adriana and Luigi Rizzi. 1988. Psych- verbs and theta- theory. Natural Language and Linguistic Theory. 6.291-352.

Bouchard, Denis. 1987. Gaps as nonprojected arguments. Proceedings of NELS 18, ed. by James Blevins and Juli Carter. 39-52. Amherst: GLSA.

Bouchard, Denis. 1990. The correspondence between conceptual structures and syntactic structures: the case of Psych constructions. Proceedings of LSRL XX, Ottawa. (forthcoming) Amsterdam: Benjamins.

Burzio, Luigi. 1981. Intransitive verbs and Italian auxiliaries. Ph. D dissertation: Cambridge MA: M.I.T.

Burzio, Luigi. 1986. Italian syntax. Dordrecht: Reidel.

Busse, Winfried \& Jean-Pierre Dubost. 1977. Französisches Verblexikon. Stuttgart: Klett.

Carlson, Gregory. 1984. On the role of thematic roles in linguistic theory. Linguistics. 22.259-279.

Carlson, Lauri. 1981. Aspect and quantification. Tense and aspect, Syntax and semantics 14. ed. by Annie Zaenen and Philip Tedeschi, 31-63. N.Y.: Academic Press.

Chomsky, Noam. 1981. Lectures on Government and Binding. Foris: Dordrecht.

Chomsky, Noam. 1986. Knowledge of Language. N.Y.: Praeger.

Dahl, Östen. 1981. On the definition of the telic - atelic (bounded - nonbounded) distinction. Tense and aspect, Syntax and semantics 14. ed. by Annie Zaenen and Philip Tedeschi, 79-90. N.Y.: Academic Press.

Dowty, David. 1988. Thematic proto-roles, subject selection, and lexical semantic defaults, 1987 LSA Colloquium paper.

Godard, Danielle. 1986. Les déterminants possessifs et les compléments de nom. Langue française, 72.102-122.

Gross, Maurice 1975. Méthodes en syntaxe. Paris: Hermann.

Haïk, Isabelle. 1990. Telling tell. Abstract of a paper at the GLOW colloquium, GLOW newsletter 24.28-29.

Jackendoff, Ray. 1987. The status of thematic relations in linguistic theory. Linguistic Inquiry. 18.369-411.

Kayne, Richard. 1980. De certaines différences entre le français et l'anglais. Langages 60.47-64.

Lamiroy, Béatrice. 1983. Les verbes de mouvement en français et en espagnol. Amsterdam: Benjamins.

Lamiroy, Béatrice. 1987a. The complementation of aspectual verbs in French. Lg. 63.278-298.

Lamiroy, Béatrice. 1987b. Les verbes de mouvement: emplois figurés et extensions métaphoriques. Langue française 76.41-58.

Melis, Ludo. 1983a. Les circonstants et la phrase. Leuven: Presses universitaires.

Melis, Ludo 1983b. The construction of the infinitive with causative movement verbs in French. In: L. Tasmowski \& D. Willems (éds) Problems in syntax Gent: Communication \& Cognition, 181194.

Milner, Jean-Claude. 1982. Ordres et raisons de langue. Paris: Seuil.

Perlmutter, David. 1970. The two verbs begin. Readings in English Transformational Grammar. ed. by Roderick Jacobs and Peter Rosenbaum, 107-120. Waltham MA: Ginn.

Pica, Pierre. (forthcoming). R-nouns.

Postal, Paul. 1974. On Raising. Cambridge MA, The MIT Press.

Pustejovsky, James. 1988. The geometry of events. Studies in generative approaches to syntax. ed. by Carol Tenny, 19-40. Lexicon Project Working Papers 24. Cambridge MA: MIT.

Rochette, Anne. 1988. Semantic and syntactic aspects of Romance sentential complementation. Ph. D. dissertation: Cambridge MA: MIT. 
Rooryck, Johan. 1988a. Les verbes de contrôle 'métaphoriques'. Revue Romane 23.3-8.

Rooryck, Johan. 1988b. Restrictions on dative cliticization in French causatives. Journal of Semantics 6.41-55.

Rooryck, Johan. 1989. Les verbes à montée et à contrôle 'ambigus'. Revue québécoise de linguistique 18.189-207.

Rooryck, Johan. 1990. Montée et contrôle: une nouvelle analyse. Le Français moderne 58.1/2.

Rooryck, Johan. 1991. Out of Control. Deriving the reference of nonexpressed infinitival subjects. (book ms., Indiana University)

Rosenbaum, Peter. 1967. The grammar of English predicate complement constructions. Cambridge MA: The MIT Press.

Ruwet, Nicolas. 1972. Théorie syntaxique et syntaxe du français. Paris: Seuil.

Ruwet, Nicolas. 1983. Montée et contrôle: une question à revoir? Revue Romane (numéro spécial) 24.17-37.

Tellier, Christine. 1989. Underived nominals and the projection principle: inherent possessors. to appear in: Proceedings of NELS 20, Pittsburgh 1989.

Tenny, Carol. 1987. Grammaticalizing aspect and affectedness. Ph. D. dissertation: Cambridge MA: MIT.

Tenny, Carol. 1988. The aspectual interface hypothesis: the connection between syntax and lexical semantics. Studies in generative approaches to syntax. ed. by Carol Tenny, 1-19. Lexicon Project Working Papers 24. Cambridge MA: MIT.

ter Meulen, Alice. 1989. The semantic properties of English aspectual verbs. to appear in: Proceedings of NELS 20, Pittsburgh, 1989.

Vendler, Zeno. 1967. Linguistics and philosophy Ithaca: Cornell University Press.

Verkuyl, Henk. 1972. On the compositional nature of the aspects. Dordrecht: Reidel.

van Voorst, Jan. 1988. Event structure. Amsterdam: John Benjamins. 